\title{
Behavioral driving through on line monitoring and activity-dependent stimulation in weakly electric fish
}

\author{
Caroline G Forlim ${ }^{1 *}$, Carlos Muñiz ${ }^{2}$, Reynaldo D Pinto ${ }^{3}$, Francisco B Rodríguez ${ }^{2}$, Pablo Varona ${ }^{2}$ \\ From Twenty Second Annual Computational Neuroscience Meeting: CNS*2013 \\ Paris, France. 13-18 July 2013
}

On line monitoring and event-driven stimulation are promising techniques for neuroscience studies, especially in behavioral experiments [1]. Weakly electric fish have an electric organ and electroreceptors to generate and detect electric fields [2]. They use their electric pulses to 'see' their environment and also to communicate, changing their inter pulse intervals depending on the behavioral context. We conducted 2 behavioral monitoring experiments with Gnathonemus petersii where stimuli were triggered by (1) the fish position in the tank and (2) the fish's own electrical activity.
(1) We built a virtual fence isolating the fish in a given area in the tank, using a camera and videoevent driven stimulation. Fast on line tracking was achieved by subtracting consecutive frames. When the fish crossed the virtual fence, electric stimuli were delivered. We observed that artificial stimuli as high frequency signals were more efficient to create a virtual fence than pre-recorded Gnathonemus petersii waveforms from another fish.

(2) We monitored in real time the electrical activity of the fish and delivered electric pulses. Fish's
A

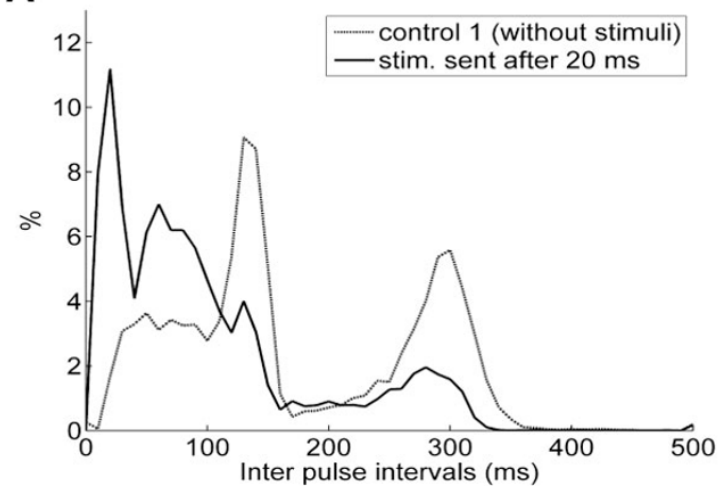

B

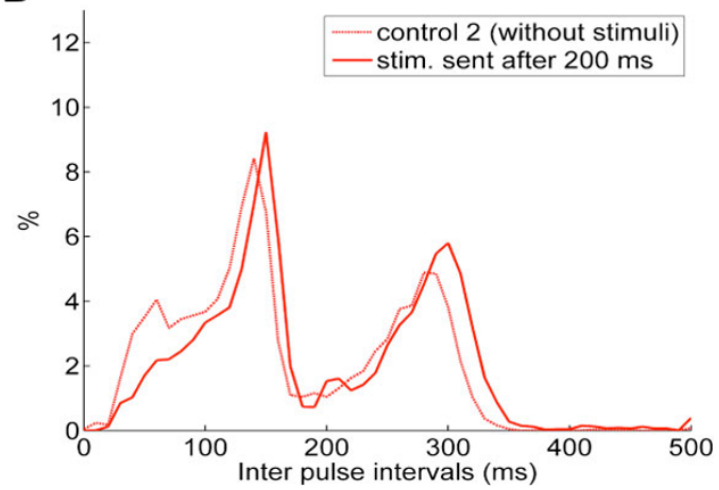

Figure $1 \mathrm{IPI}$ histograms when the fish was without stimulus for $\mathbf{3 0}$ min (dashed lines) and stimulated by a electric pulse sent $20 \mathrm{~ms}$ (A) and $200 \mathrm{~ms}$ (B) after detecting a pulse from the fish (black and red lines respectively). A. The fish increased its frequency (shorter IPIs) compared to the control with a new high peak in $11 \mathrm{~ms}$ and discharging less $130 \mathrm{~ms}$ and $300 \mathrm{~ms}$ IPIs. B. There was a decrease in the frequency of the fish (longer IPIs) under stimulation, the peaks changed from $140 \mathrm{~ms}$ to $150 \mathrm{~ms}$ and $290 \mathrm{~ms}$ to $300 \mathrm{~ms}$.

\footnotetext{
* Correspondence: carolineforlim@usp.br

'Departamento de Física Geral, Universidade de Sao Paulo, Sao Paulo, 05508-

090, Brazil

Full list of author information is available at the end of the article
}

(c) 2013 Forlim et al; licensee BioMed Central Ltd. This is an Open Access article distributed under the terms of the Creative Commons 
electrical activity was acquired in real time from 5 dipoles by a DAQ board and the pulses from the fish were detected by a computer. Once a fish's pulse was detected, a $3 \mathrm{~V}$ pulse stimulus was delivered to the fish with a delay $\tau$. Fish responded by shortening their inter pulse intervals (IPIs) for short $\tau$ values (Figure $1 \mathrm{~A})$ and discharging longer IPIS (Figure 1B) or not altering their IPIs for longer $\tau$. We tested $\tau=10 \mathrm{~ms}$, $20 \mathrm{~ms}, 50 \mathrm{~ms}, 40 \mathrm{~ms}, 70 \mathrm{~ms}$ and $100 \mathrm{~ms}$ and we obtained similar results as shown in Figure $1 \mathrm{~A}$ and $\tau=$ $160 \mathrm{~ms}, 200 \mathrm{~ms}, 280 \mathrm{~ms}, 400 \mathrm{~ms}$ with similar results as shown in Figure 1B.

\section{Acknowledgements}

This work has been supported by Brazilian agencies FAPESP, CNPq, CAPES and grants MICINN BFU2009-08473 and TIN 2010-19607, Spanish-Brazilian Cooperation PHB2007-0008 and 7a Convocatoria De PROYECTOS de COOPERACION INTERUNIVERSITARIAUAM-SANTANDER con America Latina

\section{Author details}

1Departamento de Física Geral, Universidade de Sao Paulo, Sao Paulo, 05508090, Brazil. Escuela Politécnica Superior, Universidad Autonoma de Madrid, Madrid, 28049, Spain. ${ }^{3}$ Instituto de Física de Sao Carlos, Universidade de Sao Paulo, Sao Carlos, 13560-970, Brazil.

Published: 8 July 2013

\section{References}

1. Chamorro P, Muñiz C, Levi R, Arroyo D, Rodríguez FB, et al: Generalization of the Dynamic Clamp Concept in Neurophysiology and Behavior. PLoS ONE 2012, 7(7):e40887, doi:10.1371/journal.pone.0040887.

2. Bullock TH, Hopkins CD, Popper AN, Fay RR: Eletroreception. Springer; 20051.

\section{doi:10.1186/1471-2202-14-S1-P405}

Cite this article as: Forlim et al:: Behavioral driving through on line monitoring and activity-dependent stimulation in weakly electric fish. BMC Neuroscience 2013 14(Suppl 1):P405.

\section{Submit your next manuscript to BioMed Central} and take full advantage of:

- Convenient online submission

- Thorough peer review

- No space constraints or color figure charges

- Immediate publication on acceptance

- Inclusion in PubMed, CAS, Scopus and Google Scholar

- Research which is freely available for redistribution

Submit your manuscript at www.biomedcentral.com/submit 